\title{
HIDROSTRATIGRAFI DAN DAMPAKNYA PADA KEMUNCULAN MATAAIR DI SUB-SISTEM PANGGANG, KAWASAN KARST GUNUNGSEWU, KABUPATEN GUNUNGKIDUL
}

\author{
Ahmad Cahyadi $^{\mathrm{a}}$, Indra Agus Riyanto ${ }^{\mathrm{b}}$, Tjahyo Nugroho Adjic ${ }^{\mathrm{c}}$, Tommy Andryan Tivianton ${ }^{\mathrm{d}}$, \\ Romza Fauzan Agniy ${ }^{\mathrm{e}}$, Fajri Ramadhan ${ }^{\mathrm{f}}$, Muhammad Naufal ${ }^{\mathrm{g}}$, Trihandy Cahyo Saputro ${ }^{\mathrm{h}}$ \\ a,c Kelompok Studi Karst, Fakultas Geografi Universitas Gadjah Mada, Yogyakarta \\ b,e Magister Pengelolaan Pesisir dan Daerah Aliran Sungai (MPPDAS), Fakultas Geografi, Universitas Gadjah Mada \\ d,f,g Departemen Geografi Lingkungan, Fakultas Geografi, Universitas Gadjah Mada \\ ${ }^{h}$ Departemen Teknik Geologi, Fakultas Teknik, Universitas Gadjah Mada \\ a ahmadcahyadi@geo.ugm.ac.id ; indra.agus.r@gmail.com; ${ }^{\text {a }}$ adji@geo.ugm.ac.id
}

Sub-sistem Panggang di Kawasan Karst Gunungsewu di Daerah Istimewa Yogyakarta merupakan bagian dari tinggian Gunungsewu yang berada di bagian paling barat. Zona ini secara hidrogeologi dicirikan dengan kemunculan mataair di sepanjang perbatasan dengan Graben Bantul, mataair epikarst dan mataair yang muncul di wilayah kepesisiran yang berbatasan dengan Samudera Hindia. Namun demikian, dibandingkan dengan sub-sistem lain di Gunungsewu, Sub-sistem Panggang merupakan salah satu zona yang paling sedikit dilakukan kajian ilmiah khususnya terkait dengan kondisi hidrogeologinya. Penelitian ini bertujuan untuk mengetahui kondisi stratigrafi akuifer di wilayah Sub-sistem Panggang dan kaitannya dengan kemunculan mataair pada perbatasan dengan Graben Bantul. Penelitian dilakukan di wilayah sekitar Mataair Guntur yang terletak di Desa Girijati, Purwosari, Kabupaten Gunungkidul. Data stratigrafi diambil dengan pendugaan geofisika menggunakan Geosonar. Titik-titik Geosonar didesain membentuk transek yang secara morfologi memotong Mataair Guntur mulai dari atas (puncak perbukitan) sampai dengan bagian bawah (lereng Escarpment Graben Bantul). Hasil analisis menunjukkan bahwa Mataair Guntur muncul karena jalur sungai bawah tanah terpotong oleh topografi. Pemotongan ini terjadi pada Patahan Opak yang terletak di bagian utara Karst Gunungsewu Sub-sistem Panggang. Hal ini didukung dari hasil interpretasi yang menunjukkan bahwa lapisan gamping di bawah Mataair Guntur setebal 127 - 182 meter. Hal ini menunjukkan bahwa mataair ini tidak muncul oleh kontak batuan.

Keywords: Hidrostratigrafi, Sub-sistem Panggang, Mataair, Karst Gunungsewu

\section{PENDAHULUAN}

Kusumayudha (2005) membagi Kawasan Karst Gunungsewu menjadi tiga bagian utama subsistem hidrogeologi (Gambar 1). Ketiga sub-sistem hidrogeologi tersebut adalah Sub-sistem Panggang, Sub-sistem Wonosari dan Sub-sistem Sadeng. Ketiga sub-sistem hidrogeologi tersebut masing-masing memiliki karakteristik yang khas yang membedakannya dengan susb-sistem hidrogeologi yang lain. Selama ini, penelitian di Kawasan Karst Gunungsewu lebih banyak dilakukan di Sub-sistem Wonosari. Hal ini karena pada sub-sistem ini banyak ditemukan sungai bawah tanah dengan debit yang besar. Penurunan batuan dasar pada sub-sistem ini menyebabkan aliran sungai bawah tanah terkumpul dalam sub-sistem ini, sehingga membentuk sistem hidrologi sungai bawah utama di Kawasan Karst Gunungsewu, yaitu sistem sungai bawah tanah (SBT) Bribin - Baron. 


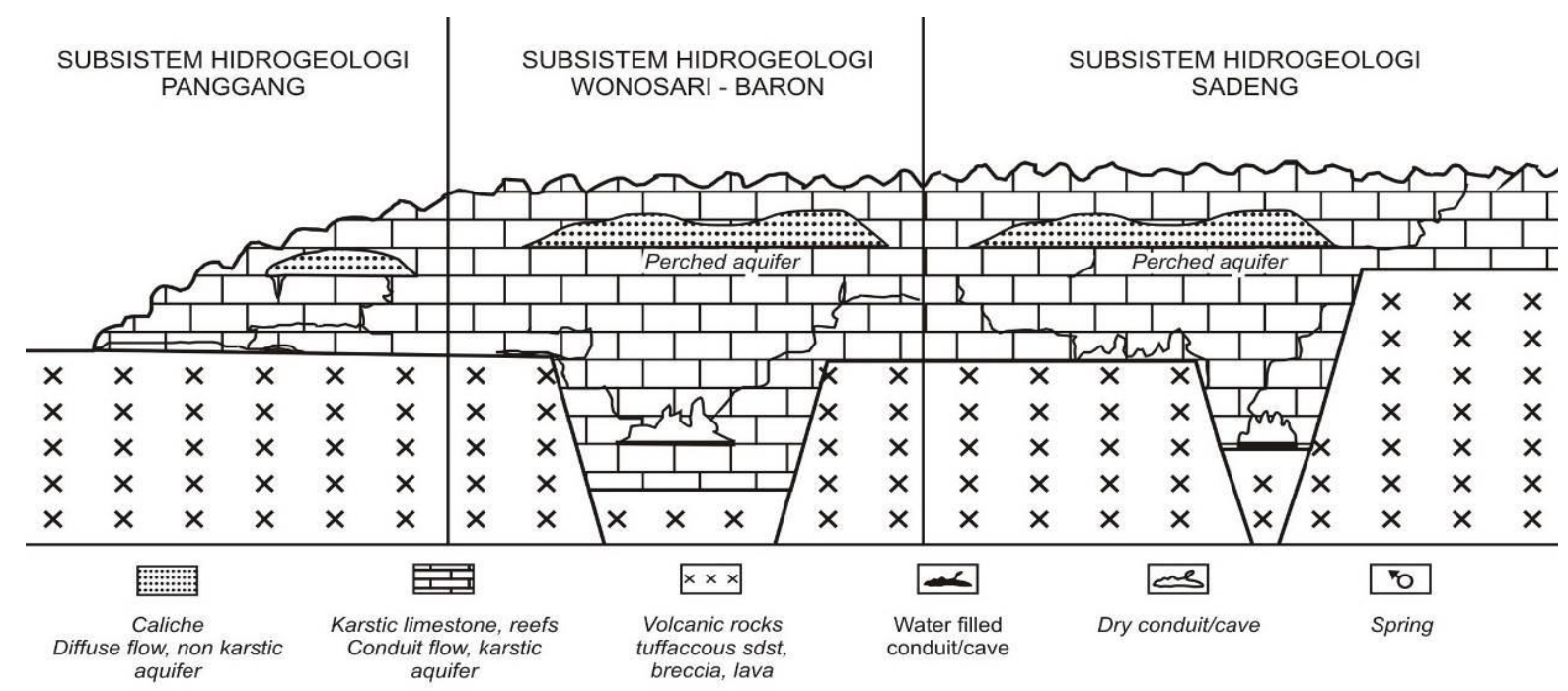

Gambar 1. Sistem Hidrogeologi di Kawasan Karst Gunungsewu (Kusumayudha, 2005)

Sub-sistem Panggang merupakan sub-sistem yang jarang dikaji di Kawasan Karst Gunungsewu Kabupaten Gunungkidul. Haryono (2011) dan Haryono dkk. (2017) menyebutkan bahwa sifat dari aliran airtanah di sub-sistem ini mengalir ke arah Utara, Barat dan Selatan (Gambar 2). Kondisi ini menyebabkan aliran sungai bawah tanah di lokasi ini cenderung kecil dan umumnya muncul sebagai mataair-mataair dengan debit-debit yang kecil pula. Beberapa mataair memiliki debit sangat kecil atau bahkan kering pada saat musim kemarau. Mataair di Sub-Sistem Panggang umumnya muncul pada perbatasan Kawasan Karst Gunungsewu dengan Graben Bantul di bagian barat dan utara, serta pada batas Karst Gunungsewu dengan Samudra Hindia di bagian selatan.

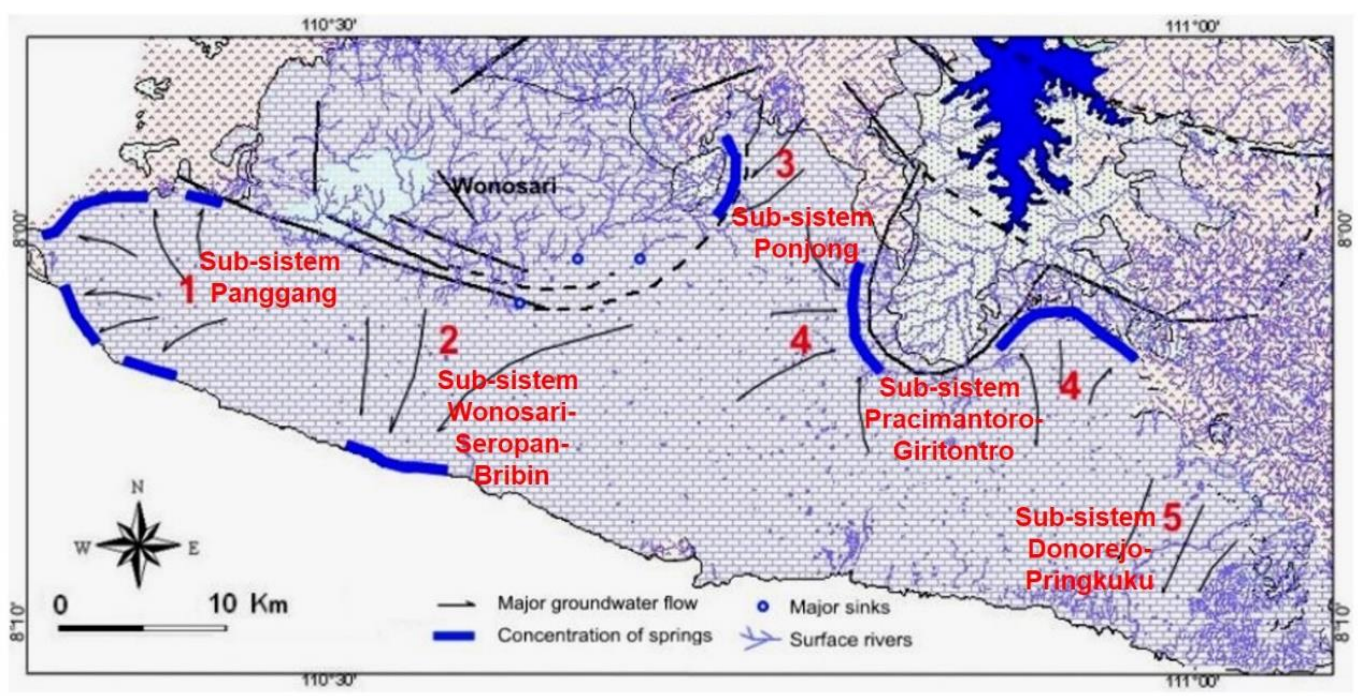

Gambar 2. Sub-sistem Hidrogeologi Menurut Haryono (2011), Konsentrasi Mataair dan Arah Aliran Airtanah Dominannya 
Makalah ini dipresentasikan dalam Seminar Nasional Geografi II yang diselenggarakan oleh Himpunan Mahasiswa Pascasarjana Geografi (HMPG), Fakultas Geografi UGM di Yogyakarta tanggal 17 November 2018

Penelitian terdahulu misalnya yang disebutkan oleh Kusumayudha (2005) menyebutkan bahwa keberadaan mataair di Bagian Utara Sub-sistem Panggang terbentuk karena adanya kontak antara batuan gamping di bagian atas dengan batuan vulkanik yang menjadi alas (Gambar 3). Kesimpulan ini umumnya ditarik dari tinjauan kondisi geologi permukaan dan sangat sedikit data bawah permukaan seperti data geofisika dan data bor. Oleh karenanya, penelitian ini bertujuan untuk menganalisis kondisi hidrostratigrafi di Sub-sistem Panggang dan pengaruhnya terhadap kemunculan mataair di sub-sistem ini. Penelitian mengambil contoh kasus di sekitar Mataair Guntur, Desa Girijati, Kecamatan Purwosari, Kabupaten Gunungkidul.

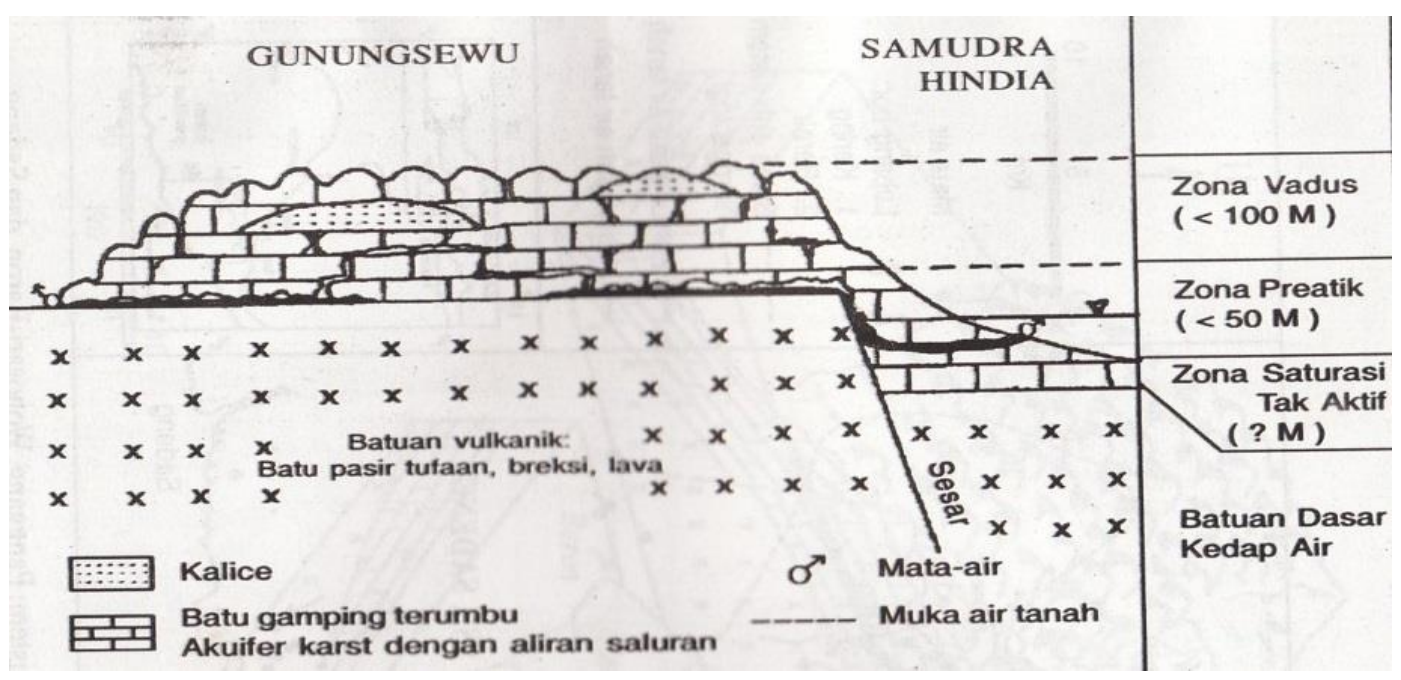

Gambar 3. Profil Konseptual Sub-sistem Panggang Berarah Utara-Selatan yang Menunjukkan Kemunculan Mataair pada Zona Kontak Batuan (Kusumayudha, 2005)

\section{METODE PENELITIAN}

Alat dan bahan yang digunakan dalam poenelitian ini meliputi Geosonar, peta geologi, peta rupa Bumi Indonesia (RBI), perlengkapan survei lapangan seperti Global Positioning System (GPS) Receiver, palu geologi, dan kompas geologi. Geosonar adalah peralatan geofisika aktif yang memancarkan frekuensi UHF untuk mengetahui material di bawah permukaan Bumi. Frekuensi yang dipancarakan Geosonar akan dialirkan secara scanning dan menghasilkan data material dan kondisi bawah permukaan berdasarkan pada respon pantulan dari masing-masing material yang dilewati. Pengambilan data dilakukan secara transek mulai dari perbukitan karst sampai dengan lereng escarpment Graben Bantul (Gambar 4). Transek tersebut dibuat melewati Mataair Guntur yang merupakan studi kasus dalam penelitian ini. Hasil akuisisi data dengan Geosonar kemudian divalidasi dengan survei geologi lapangan dan membandingkan dengan hasil-hasil penelitian terdahulu. Data yang dihasilkan berupa titik-titik data 
Makalah ini dipresentasikan dalam Seminar Nasional Geografi II yang diselenggarakan oleh Himpunan Mahasiswa Pascasarjana Geografi (HMPG), Fakultas Geografi UGM di Yogyakarta tanggal 17 November 2018

log yang kemudian dianalisis korelasinya untuk menghasilkan kondisi hidrostratigrafi di lokasi kajian. Hasil tersebut akan menunjukkan posisi dari Mataair Guntur dalam hidrostratigrafi dan diketahui kontrol hidrostratigrafi yang berpengaruh pada kemunculan mataair ini.

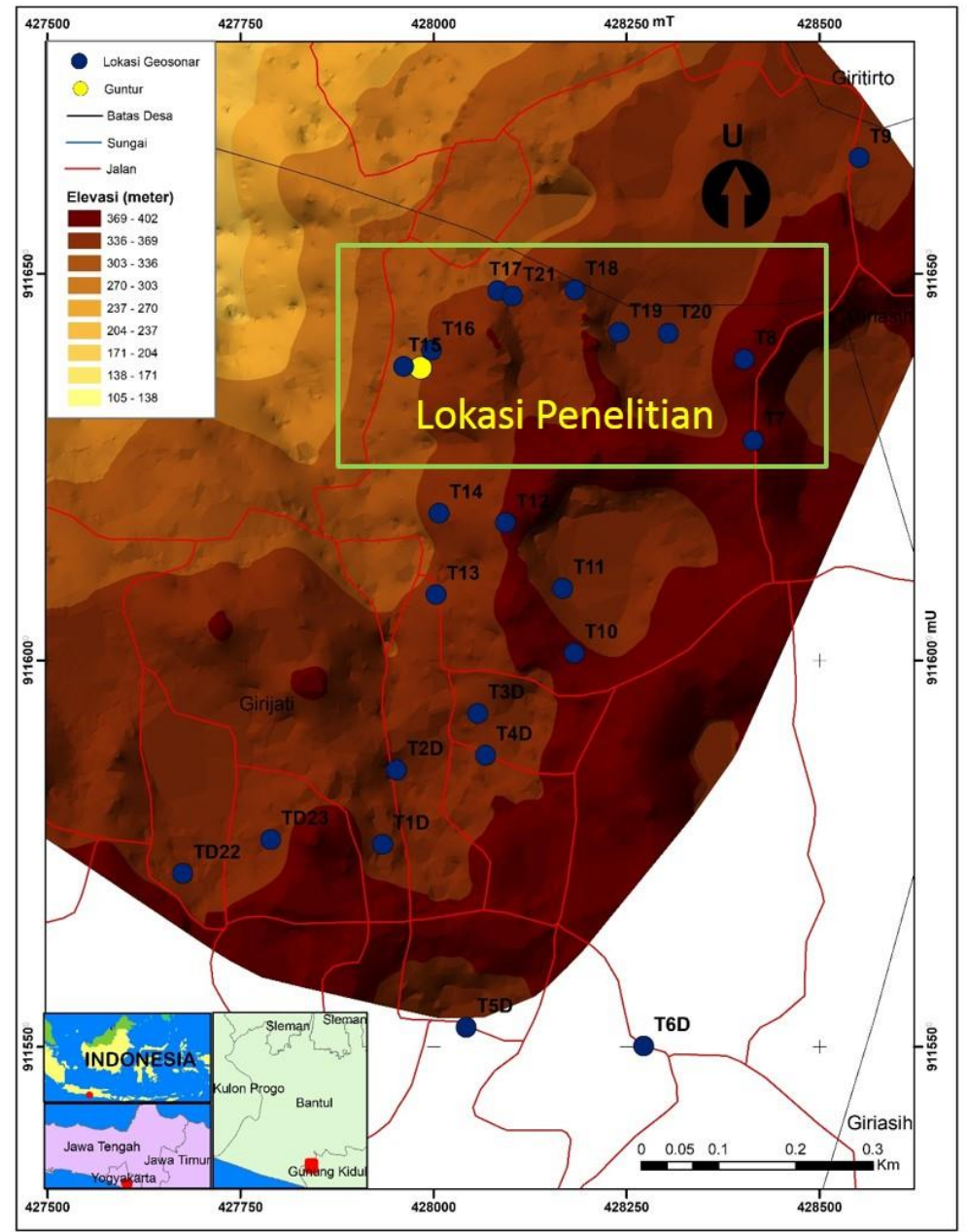

Gambar 4. Lokasi Penelitian (Kotak Hijau)

\section{HASIL DAN PEMBAHASAN}

Hasil analisis terhadap data geosonar (Gambar 5 dan Gambar 6) menunjukkan bahwa bagian dasar dari batu gamping adalah material gunungapi yang didominasi oleh material pasir dan andesit. Material vulkanik ini tidak lepas dari keberadaan Gunungapi Parangtritis (Hartono, 2000; hartono dan Bronto, 2007) yang lokasinya berada di sebelah barat lokasi kajian. Material vulkanik ini berdasarkan pada peta geologi lembar Yogyakarta skala 1:100.000 (Raharjo dkk, 1995) merupakan bagian dari Formasi Nglanggeran yang merupakan mengalasi gamping di kawasan karst Gunungsewu (Sunarto dkk., 2017). Material vulkanik ini juga merupakan dari gunungapi tersier yang menurut Bemmelen (1949) merupakan bagian dari old andesite formation yang didominasi oleh batuan andesitik-basaltik. 
Makalah ini dipresentasikan dalam Seminar Nasional Geografi Il yang diselenggarakan oleh Himpunan Mahasiswa Pascasarjana Geografi (HMPG), Fakultas Geografi UGM di Yogyakarta tanggal 17 November 2018

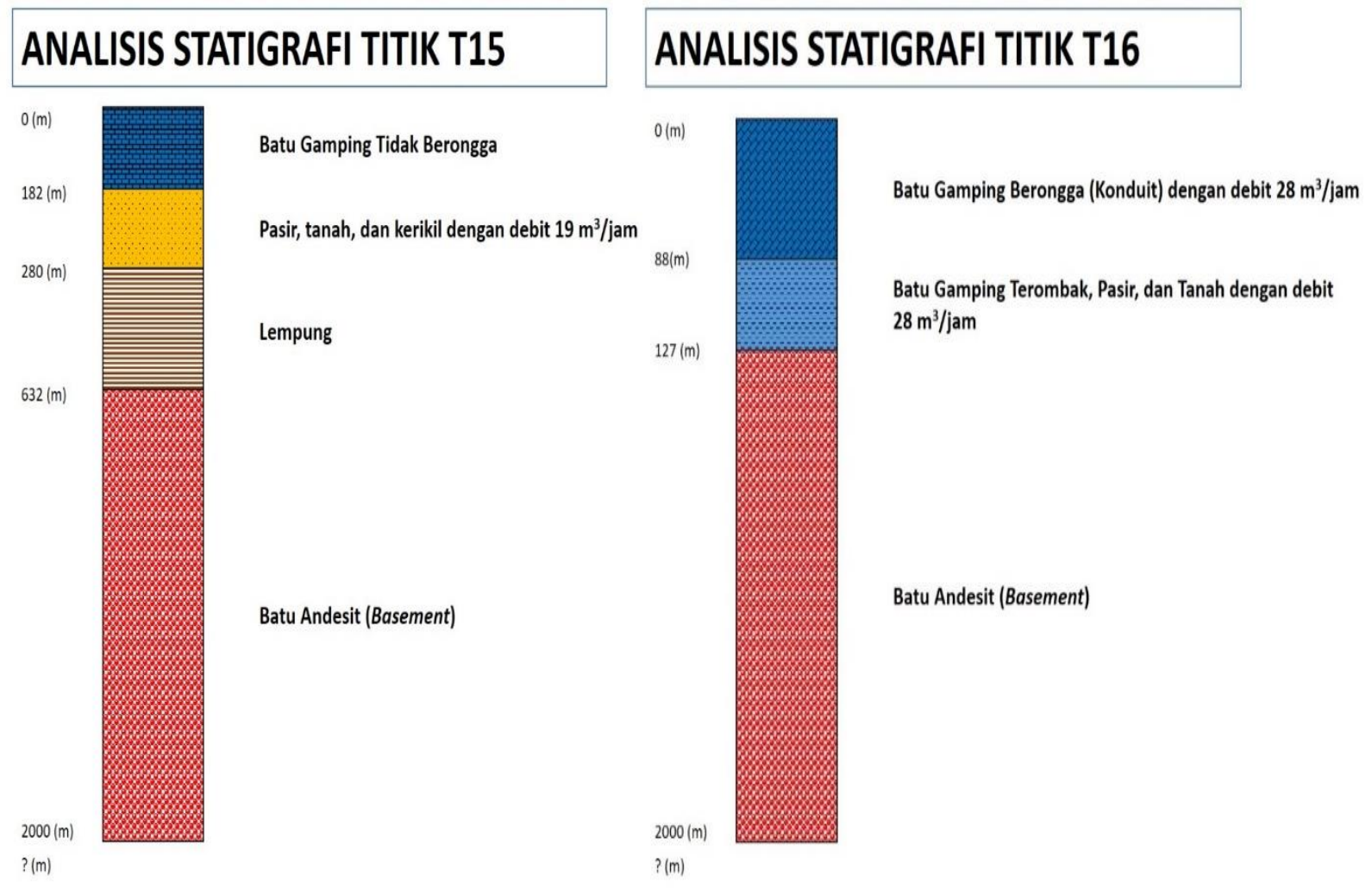

\section{ANALISIS STATIGRAFI TITIK T17}

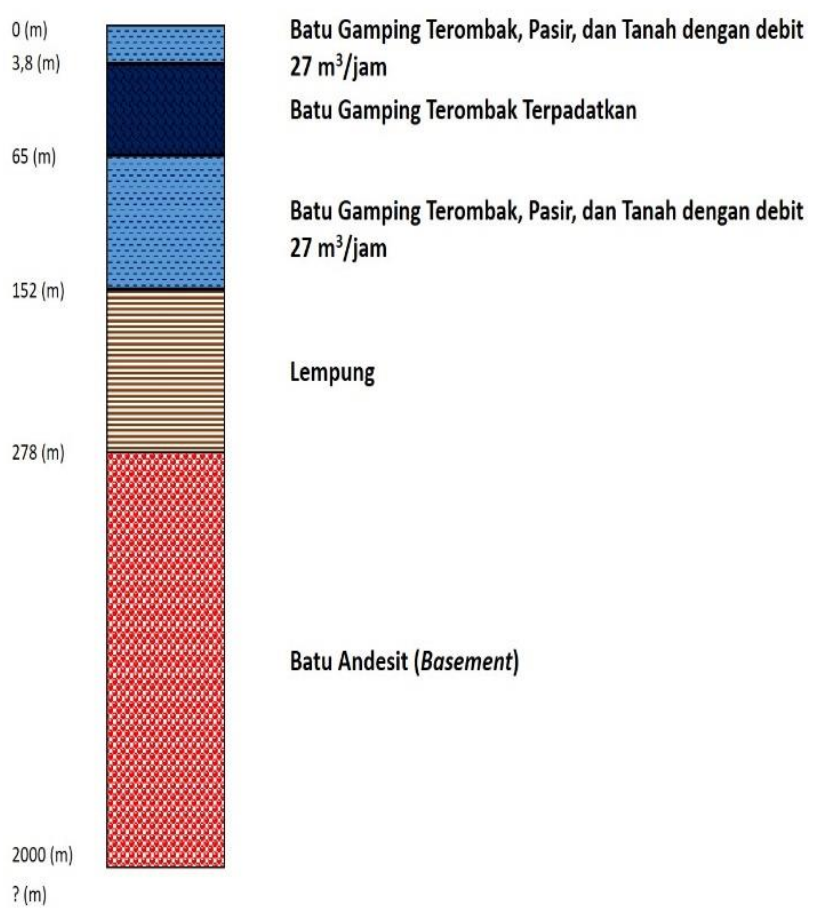

Gambar 5. Hasil Analisis Geosonar di Sekitar Mataair Guntur (Bagian I) 
Makalah ini dipresentasikan dalam Seminar Nasional Geografi II yang diselenggarakan oleh Himpunan Mahasiswa Pascasarjana Geografi (HMPG), Fakultas Geografi UGM di Yogyakarta tanggal 17 November 2018

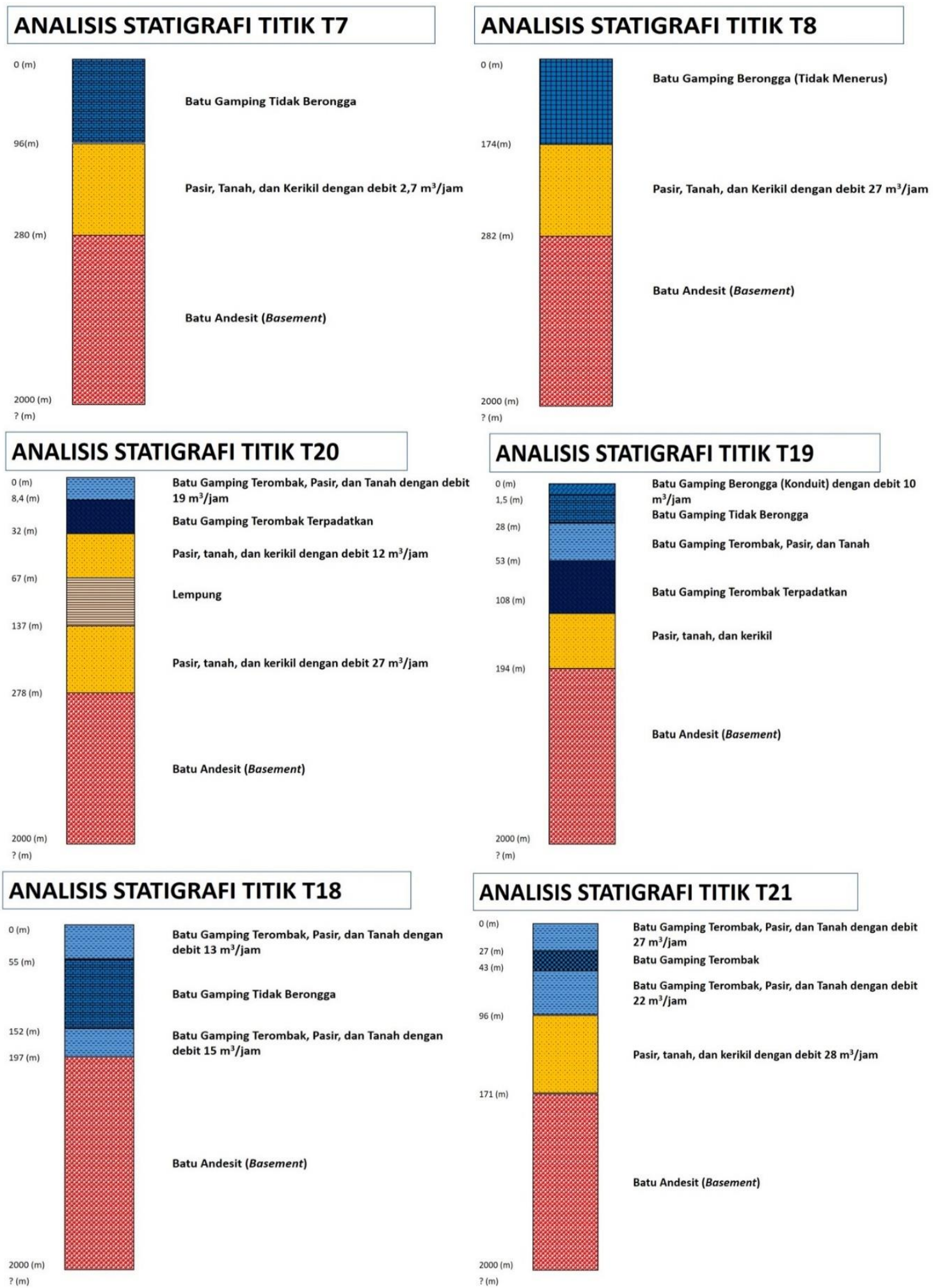

Gambar 6. Hasil Analisis Geosonar di Sekitar Mataair Guntur (Bagian II) 
Makalah ini dipresentasikan dalam Seminar Nasional Geografi Il yang diselenggarakan oleh Himpunan Mahasiswa Pascasarjana Geografi (HMPG), Fakultas Geografi UGM di Yogyakarta tanggal 17 November 2018

Lorong konduit/ gua terdeteksi pada titik T15 dan T16. T16 adalah lokasi di dekat Mataair Guntur. Ketebalan gamping dibawah lorong konduit pada kedua titik ini adalah 127 meter sampai dengan 182 meter. Hal ini menunjukkan bahwa lorong konduit dari Mataair Guntur tidak muncul pada kontak batuan antara gamping dan batuan volkanik.

Hasil penelitian yang dilakukan oleh Wisyatuti et.al. (2018), menunjukkan bahwa di sekitar lokasi kajian terdapat terdapat beberapa sinkhole (Gambar 7) dan ponor. Penelitian lain yang dilakukan oleh Cahyadi dkk. (2018a) menyebutkan bahwa Mataair Guntur terhubung dengan Sungai Bawah Tanah Nangka (Gambar 8) di bagian atas dari Mataair Guntur. Hal ini menunjukkan bahwa Mataair Guntur merupakan resurgence dari Sungai Bawah Nangka yang kemudian muncul dipermukaan karena terpotongnya topografi. Pemotongan topografi disebabkan karena adanya patahan Opak (Notosiswoyo and Kusumayudha (1998) dan Cahyadi dkk (2018b) yang memotong bagian utara dari perbukitan Karst Gunungsewu. Hal yang sama juga dapat diamati pada beberapa mataair yang terdapat di sekitar lokasi kajian, seperti Mataair Nganjan di Dusun Turunan, Desa Girisuko, Panggang, Gunungkidul (Gambar 9) dan Gua Cerme di Dusun Ploso, Desa Giritirto, Kecamatan Panggang, Gunungkidul.

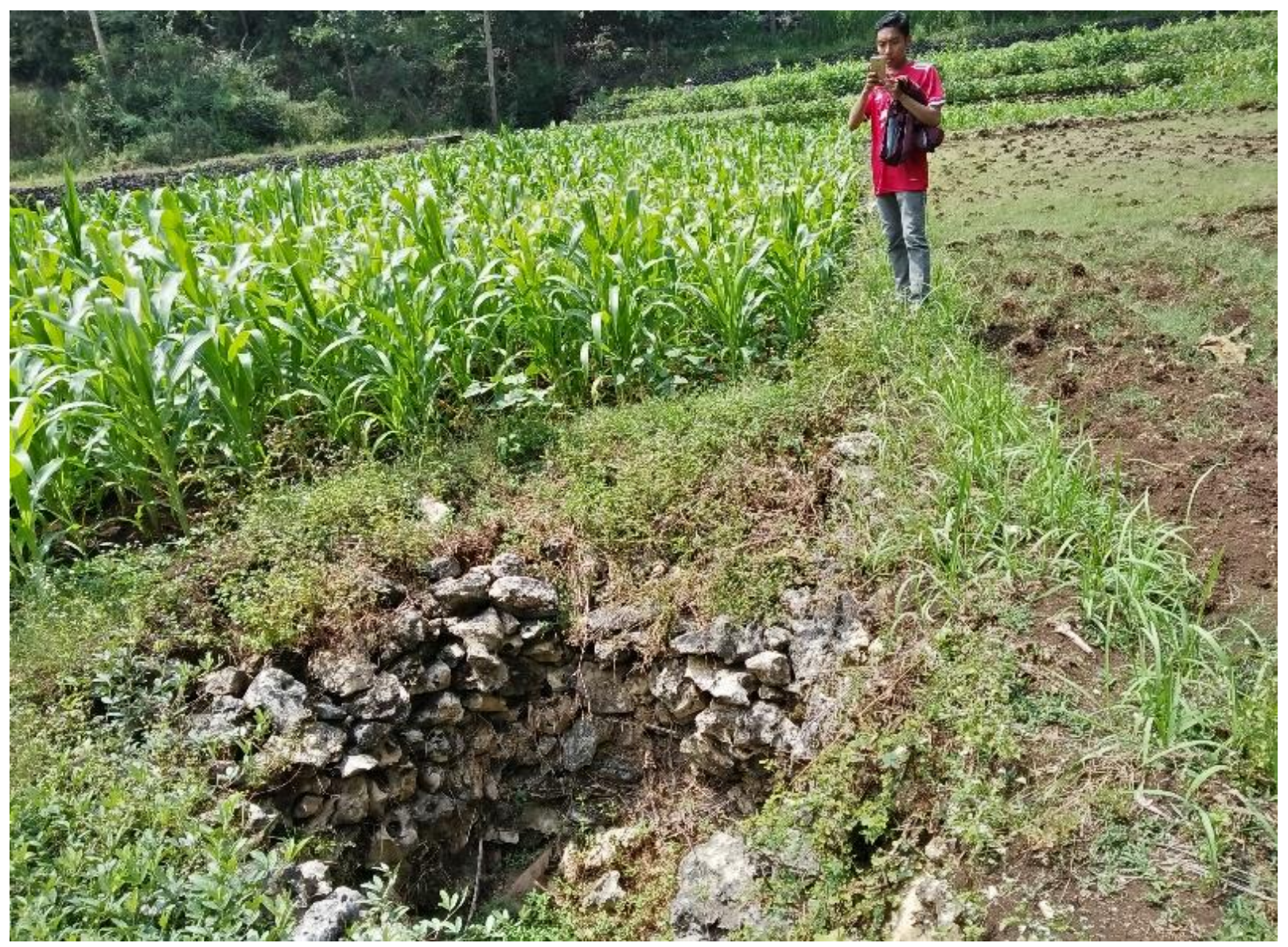

Gambar 7. Salah Satu Sinkhole di Sekitar Lokasi Kajian 
Makalah ini dipresentasikan dalam Seminar Nasional Geografi Il yang diselenggarakan oleh Himpunan Mahasiswa Pascasarjana Geografi (HMPG), Fakultas Geografi UGM di Yogyakarta tanggal 17 November 2018

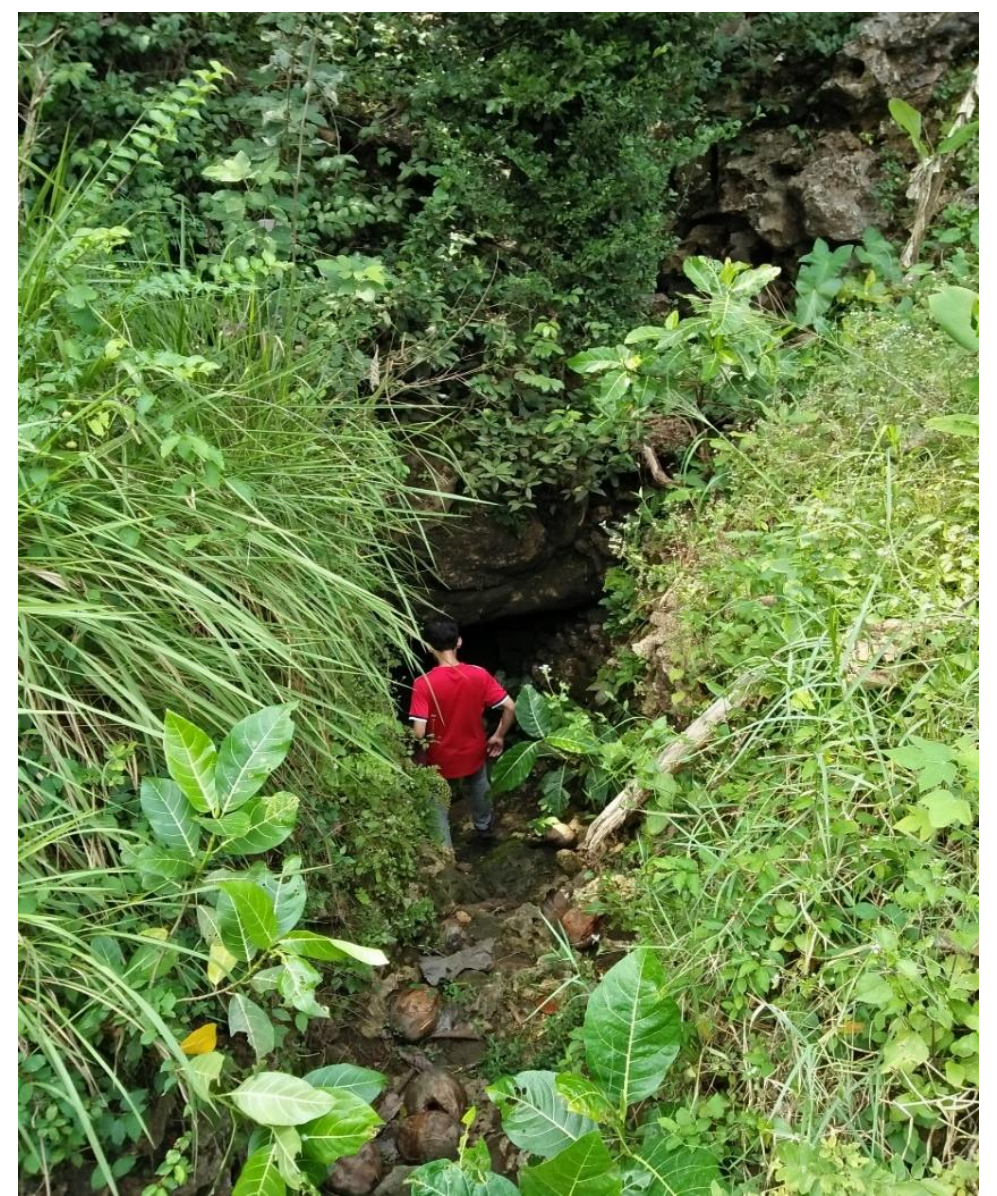

Gambar 8. Mulut Gua Sungai Bawah Tanah Nangka (Kali Nangka)

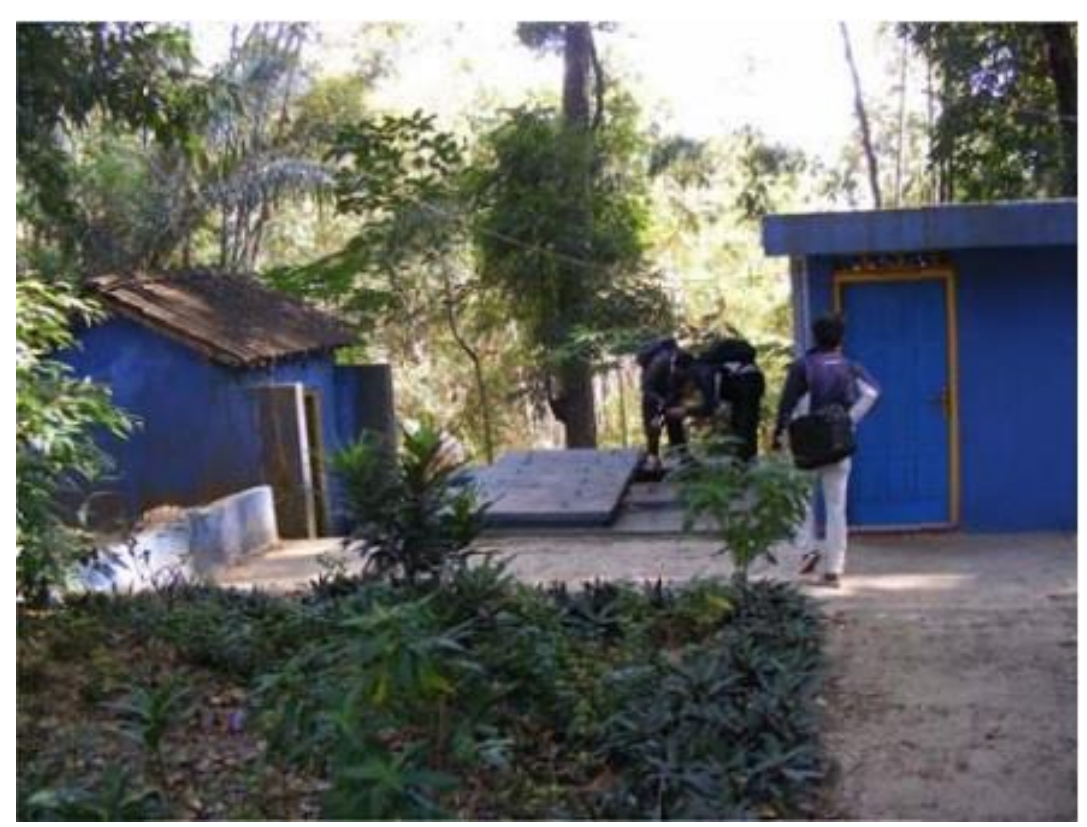

Gambar 9. Mataair Nganjan di Girisuko, Panggang Merupakan Mataair yang Muncul Karena Pemotongan Topografi oleh Sesar Opak di Bagian Utara Kawasan Karst Gunungsewu Sub-sistem Panggang (Cahyadi dkk., 2012) 
Makalah ini dipresentasikan dalam Seminar Nasional Geografi II yang diselenggarakan oleh Himpunan Mahasiswa Pascasarjana Geografi (HMPG), Fakultas Geografi UGM di Yogyakarta tanggal 17 November 2018

Letak Mataair Guntur yang berada di bagian atas perlapisan gamping menyebabkan lapisan di atasnya yang berfungsi sebagai pemyimpan air tipis dan memiliki simpanan airtanah yang terbatas. Hal ini seperti yang disampaikan oleh Haryono (2011) dan Haryono dkk. (2017) yang menyatakan bahwa mataair di sub-sistem Panggang didominasi oleh mataair epikarst. Kondisi tersebut menyebabkan simpanan yang relatif kecil, sehingga kondisi mataair pada musim kemarau menjadi kering atau dengan debit yang sangat kecil (Gambar 10).

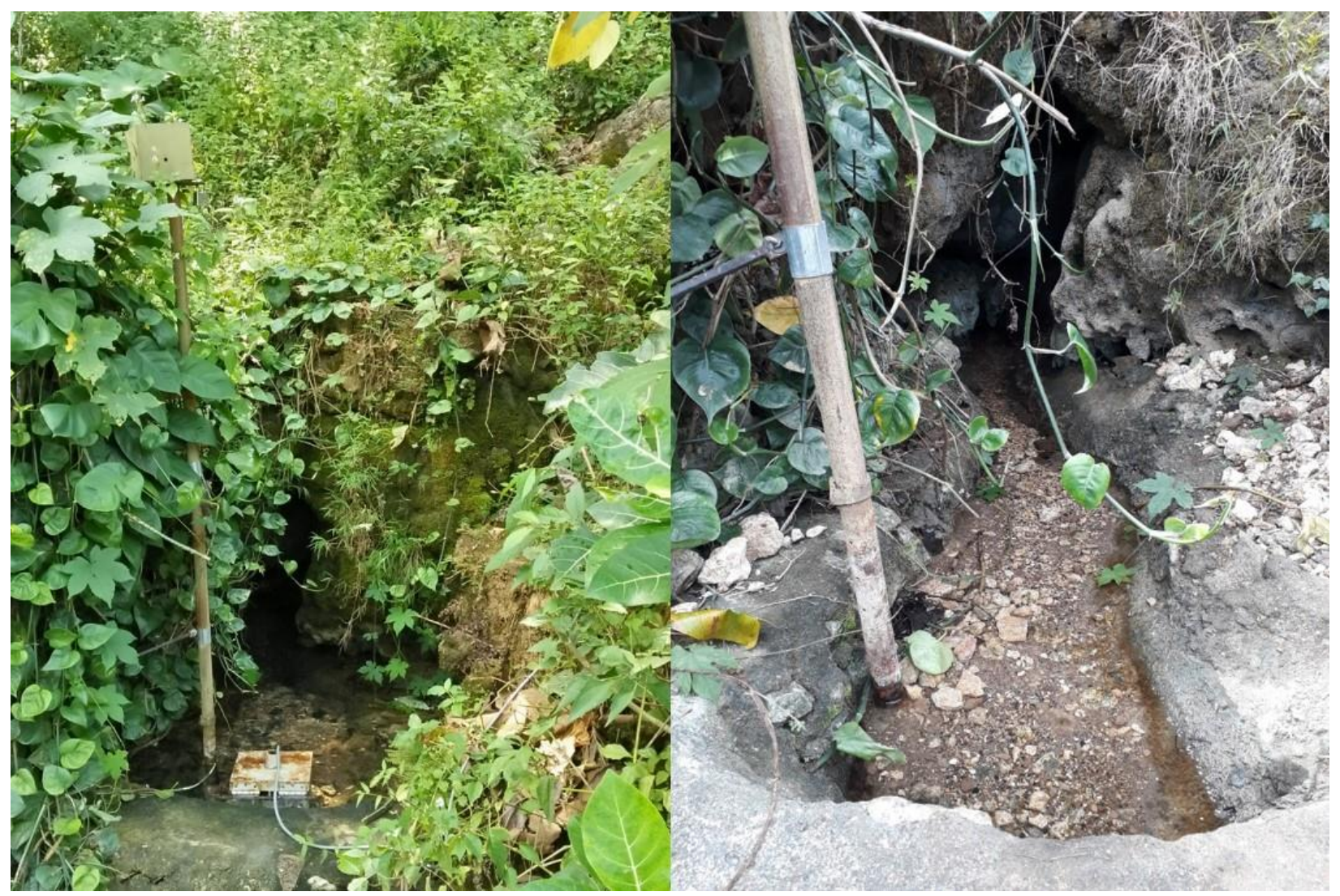

Gambar 10. Kondisi Mataair Guntur di Musim Penghujan (Kiri) dan pada Musim Kemarau (Kanan)

\section{KESIMPULAN}

Berdasarkan hasil penelitian yang telah dilakukan, maka diketahui bahwa Mataair Guntur muncul pada bagian atas lapisan gamping. Kemunculannya disebabkan karena terppotongnya sungai bawah tanah oleh patahan Opak. Kedalaman bataun dasar pada Mataair Guntur adalah 127 meter sampai dengan 182 meter. Hal tersbeut menunjukkan bahwa kemunculan Mataair Guntur tidak disebabkan oleh kontak batuan. 
Makalah ini dipresentasikan dalam Seminar Nasional Geografi II yang diselenggarakan oleh Himpunan Mahasiswa Pascasarjana Geografi (HMPG), Fakultas Geografi UGM di Yogyakarta tanggal 17 November 2018

\section{PENGAKUAN}

Penelitian ini merupakan bagian dari penelitian yang berjudul "Karakterisasi Resesi Hidrograf Aliran Karst untuk Penentuan Kapasitas Simpanan Air pada Beberapa Tipe Perkembangan Karst untuk Antisipasi Bencana Kekeringan". Penelitian ini dibiayai oleh Kementerian Riset, Teknologi dan Pendidikan Tinggi Republik Indonesia melalui skema Penelitian Dasar Unggulan Perguruan Tinggi (PDUPT) tahun 2018 dengan nomor kontrak 38/UN1/DITLIT/DIT-LIT/LT/2018.

\section{REFERENSI}

Bemmelen, van, R.W. 1949. The Geology of Indonesia. Martinus Nyhoff, The Haque. Nederland.

Cahyadi, A.; Nugraha, H.; Wacano, D. dan Fatchurohman, H. 2012. Peran Organisasi Masyarakat dalam Startegi Adaptasi Kekeringan di Dusun Turunan, Kecamatan Panggang, Kabupaten Gunungkidul (Sebuah Pembelajaran dalam Adaptasi Dampak Perubahan Iklim di Masa Mendatang). Prosiding Seminar Nasional Perubahan Iklim. Yogyakarta: Sekolah Pascasarjana Universitas Gadjah Mada.

Cahyadi, A.; Riyanto, A.I.; Lestari, S.F. dan Listyaningrum, N. 2018a. Peningkatan Kapasitas Masyarakat Desa Girijati, Kecamatan Purwosari, Kabupaten Gunungkidul dalam Konservasi Kawasan Karst. Laporan Hibah Pengembangan Program Pengabdian Kepada Masyarakat Fakultas Geografi UGM 2018. Yogyakarta: Fakultas Geografi Universitas Gadjah Mada.

Cahyadi, A.; Riyanto, I.; Irshabdillah, M.R. dan Firizqi, F. 2018b. Inventarisasi dan Karakterisasi Sistem Aliran Sungai Alogenik di Kawasan Karst Gunungsewu Kabupaten Gunungkidul. Laporan Hibah Penelitian Dosen Fakultas Geografi UGM 2018. Yogyakarta: Fakultas Geografi Universitas Gadjah Mada.

Hartono, G. 2000. Studi Gunung Api Tersier: Sebaran Pusat Erupsi dan Petrologi di Pegunungan Selatan Yogyakarta. Tesis. Bandung: Institut Teknologi Bandung.

Hartono, G. dan Bronto, S. 2007. Asal-usul Pembentukan Gunung Batur di Daerah Wediombo, Gunungkidul, Yogyakarta. Jurnal Geologi Indonesia, 2(3): 143-158.

Haryono, E. 2011. Introduction to Gunungsewu Karst. Field Guide of Asian Trans-Disciplinary Karst Conference. Yogyakarta: Karst Research Group, Faculty of Geography, Universitas Gadjah Mada.

Hayono, E.; Barianto, D.H. dan Cahyadi, A. 2017. Hidrogeologi Kawasan Karst Gunungsewu: Panduan Lapangan Fieldtrip PIT PAAI ke-2. Yogyakarta: Perhimpunan Ahli Airtanah Indonesia (PAAI).

Kusumayudha, S.B. 2005. Hidrogeologi Karst dan Geometri Fraktal di Daerah Karst Gunungsewu. Yogyakarta: Adicita. 
Makalah ini dipresentasikan dalam Seminar Nasional Geografi Il yang diselenggarakan oleh Himpunan Mahasiswa Pascasarjana Geografi (HMPG), Fakultas Geografi UGM di Yogyakarta tanggal 17 November 2018

Notosiswoyo, S. and Kusumayudha, S.B. 1998. Hydrogeology of The Gunungsewu Karstic Area, Central Java, Indonesia: A Conceptual Model. Proceeding of Ninth Regional Congress on Geology, Mineral and Energy Resources of South East Asia. Kuala Lumpur.

Raharjo, W., Sukandarrumidi dan Rosidi, H.M.D. 1995. Peta Geologi Lembar Yogyakarta, Jawa Skala 1: 100.000. Bandung: Pusat Penelitian dan Pengembangan Geologi.

Sunarto; Marfai, M.A.; Gunawan, T.; Murti, S.G.; Cahyadi, A.; Fatchurohman, H.; dan Malawani, M.N. 2017. Karakteristik Akuifer Wilayah Kepesisiran Parangtritis, Kabupaten Bantul. Prosiding Seminar Nasional Geografi I. Yogyakarta: Program Pascasarjana Geografi, Fakultas Geografi, Universitas Gadjah Mada.

Wdyastuti, M.; Riyanto, I.A.; Naufal, M.; Ramadhan, F. and Rahmawati, N. 2018. Water Catchement Area Analysis of Guntur Karst Spring. The Second International Conference on Environmental Resources Management in Global Region. Yogyakarta: Universitas Gadjah Mada. 